Rapp. Grønlands geol. Unders. 112, 83-94 (1983)

\title{
Fe-Ti oxides in the Malene supracrustals and the occurrence of $\mathrm{Nb}$-rich rutile
}

\author{
Robert F. Dymek
}

\begin{abstract}
Data are presented on Fe-Ti oxide compositions and assemblages in Malene supracrustal rocks from the Godthåb District and surrounding territory, West Greenland. Amphibolite facies samples contain ilmenite \pm rutile, in which the ilmenite has a low $\mathrm{Fe}_{2} \mathrm{O}_{3}$-content ( $<6$ mole \%). Granulite facies samples contain ilmenite \pm rutile, and ilmenite \pm magnetite \pm hematite, in which the $\mathrm{Fe}_{2} \mathrm{O}_{3}$-content of ilmenite ranges to $\sim 15$ mole \%. In all cases, ilmenite contains only small quantities of $\mathrm{MgO}$ and $\mathrm{MnO}$, and magnetite is virtually pure $\mathrm{Fe}_{3} \mathrm{O}_{4}$.

The above observations suggest that granulite facies samples are more oxidized than amphibolite facies ones, contrary to expectation. Possible causes include (1) re-equilibration during retrograde metamorphism, or (2) $\mathrm{H}_{2} \mathrm{O}$-dissociation to $\mathrm{H}_{2}$ and $\mathrm{O}_{2}$ with subsequent loss of hydrogen producing a more oxidizing local environment during prograde metamorphism.

In amphibolite facies 'cordierite anthophyllite rocks' (CAR), Fe-Ti oxide assemblages are related systematically to silicate mineralogy: rutile occurs in $\mathrm{Mg}$-rich samples, and ilmenite is found in Fe-rich ones, with ilmenite \pm rutile present in samples with intermediate $\mathrm{Fe} / \mathrm{Mg}$. Rutile is modally abundant (up to $\sim 3 \mathrm{vol} \%$ ), and contains high $\mathrm{Nb}_{2} \mathrm{O}_{5}$ (up to $\sim 6 \mathrm{wt} \%$ ), which suggests an absolute Nb-enrichment in CAR by a mechanism not well understood.
\end{abstract}

\section{Introduction}

The Fe-Ti oxides (hematite, magnetite, ilmenite and rutile) are common accessory phases in metamorphic rocks, with the occurrence of each mineral or assemblage of minerals being controlled by several factors including rock composition, oxygen fugacity, temperature and pressure. It is apparent from the literature that Fe-Ti oxides in metamorphic rocks have not received the kind of detailed systematic study carried out on their counterparts in igneous rocks. Nevertheless, the recent summary by Rumble (1976) has established the broad characteristics of oxides in metamorphic rocks which provides a reasonable framework for additional study of these minerals.

This paper describes the occurrence and chemistry of Fe-Ti oxides in the Archaean Malene supracrustal rocks of southern West Greenland, and reports the discovery of $\mathrm{Nb}$-rich rutile in certain 'cordierite-anthophyllite' rocks, which raises intriguing questions concerning the origin of the sedimentary protolith for this rock type. 


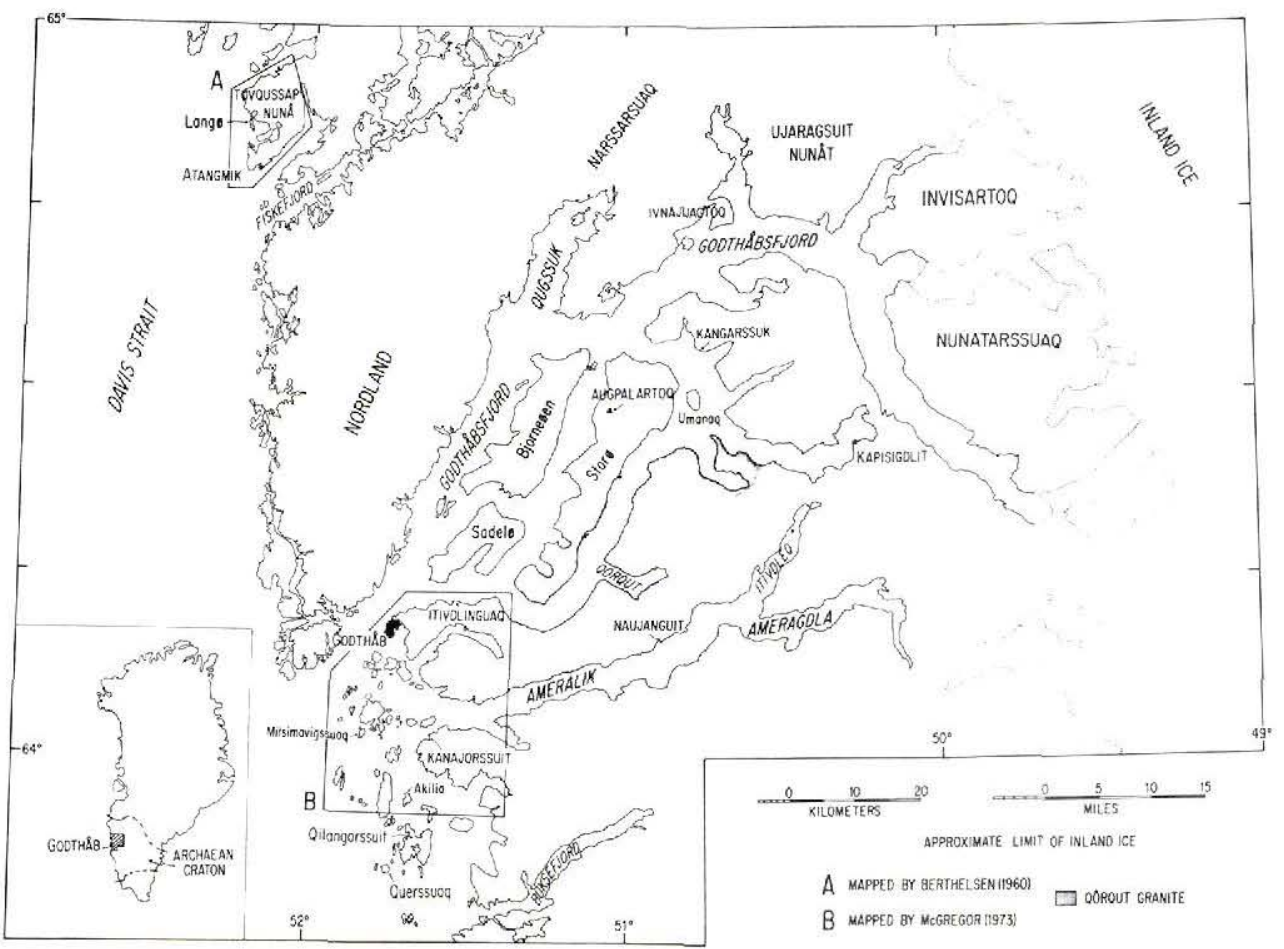

Fig. 1. General map of the Godthåb District and surrounding region of West Greenland illustrating locations referred to in the text. Boundaries of the Qôrqut Granite Complex are adapted from Brown et al. (1981).

\section{Geological overview}

The Malene supracrustal rocks were defined by McGregor (1973) to include various types of amphibolite and metasediment in the vicinity of Godthåb which are intruded by $\sim 3000$ Ma Nûk orthogneiss and are largely in tectonic contact with $\sim 3750$ Ma Amitsoq orthogneiss. This name has subsequently been applied throughout the Archaean gneiss complex of West Greenland to all supracrustal rocks with lithological characteristics and stratigraphic position similar to the ones originally described by McGregor (cf. Bridgwater et al., 1976). This convention is adopted here, and Fe-Ti oxides from two associations of Malene supracrustal rocks are described: granulite-grade occurrences from Langø, and amphibolite-grade occurrences from the Godthåbsfjord-Ameralik region.

Langø is a small island $\sim 75 \mathrm{~km}$ north of Godthåb (lat. $64^{\circ} 52^{\prime} \mathrm{N}$, long. $52^{\circ} 12^{\prime} \mathrm{W}$ ) (fig. 1). It occurs on the western flank of the Tovqussaq dome, the structure of which was described in detail by Berthelsen (1960). Dymek \& Albee (1976) and Dymek (1977a) have reported on the petrology of the rocks on Langø, and noted petrographic and mineral-chemical evidence for a prograde granulite facies metamorphism and a retrograde amphibolite facies metamorphism.

The Godthåbsfjord-Ameralik region includes the area mapped by McGregor (1973), and 
the country to the northeast, west and southeast. Metamorphism of the Malene supracrustals in this region has been described by Dymek (1977b, 1978). A prograde amphibolite facies metamorphism was followed locally by retrogression to greenschist facies.

\section{Results and sample description}

\section{Godthåbsfjord-Ameralik region}

Amphibolites. Hornblende-plagioclase-quartz amphibolites represent the dominant supracrustal lithology. Types that contain garnet, cummingtonite, anthophyllite or diopside in addition to hornblende are also present, and may be quite abundant locally. Biotite is a common accessory phase in all amphibolites, and minor amounts of apatite, tourmaline, allanite, zircon and sulfide minerals ( $\mathrm{Py} \pm \mathrm{Po} \pm \mathrm{Ccp}$ ) may also occur.

Ilmenite is the only $\mathrm{Fe}-\mathrm{Ti}$ oxide found in the amphibolites, where it typically forms

Table 1. Microprobe analyses of ilmenite (Godthåbsfjord-Ameralik region)

\begin{tabular}{lrrrrr}
\hline & \multicolumn{1}{c}{1} & \multicolumn{1}{c}{2} & \multicolumn{1}{c}{3} & \multicolumn{1}{c}{4} & \multicolumn{1}{c}{5} \\
\hline $\mathrm{SiO}_{2}$ & 0.09 & 0.03 & 0.11 & 0.14 & 0.08 \\
$\mathrm{TiO}_{2}$ & 50.85 & 51.65 & 50.00 & 50.69 & 49.76 \\
$\mathrm{Al}_{2} \mathrm{O}_{3}$ & 0.00 & 0.00 & 0.00 & 0.00 & 0.00 \\
$\mathrm{Cr}_{2} \mathrm{O}_{3}$ & 0.01 & 0.18 & 0.00 & 0.04 & 0.00 \\
$\mathrm{Fe}_{2} \mathrm{O}_{3}{ }^{\star}$ & 3.02 & 1.28 & 5.01 & 3.66 & 5.77 \\
$\mathrm{FeO}$ & 43.61 & 43.98 & 42.74 & 44.59 & 42.89 \\
$\mathrm{Mg0}$ & 0.10 & 0.46 & 1.09 & 0.40 & 0.91 \\
$\mathrm{ZnO}$ & 0.12 & 0.00 & 0.00 & 0.00 & 0.00 \\
$\mathrm{MnO}$ & 1.82 & 1.63 & 0.28 & 0.28 & 0.25 \\
$\mathrm{ZrO} \mathrm{O}_{2}$ & 0.00 & 0.00 & 0.05 & 0.00 & 0.00 \\
$\mathrm{Nb}_{2} \mathrm{O}_{5}$ & 0.00 & 0.07 & 0.12 & 0.19 & 0.18 \\
$\mathrm{Total}$ & 99.62 & 99.28 & 99.40 & 99.99 & 99.84 \\
\hline
\end{tabular}

FORHULA PROPORTLONS BASED ON 2 CATIONS ANO 3 OXYGENS

\begin{tabular}{lccccc}
$\mathrm{Si}$ & 0.002 & 0.001 & 0.003 & 0.004 & 0.002 \\
$\mathrm{Ti}$ & 0.970 & 0.985 & 0.947 & 0.962 & 0.943 \\
$\mathrm{Al}$ & 0.000 & 0.000 & 0.000 & 0.000 & 0.000 \\
$\mathrm{Cr}$ & 0.000 & 0.004 & 0.000 & 0.001 & 0.000 \\
$\mathrm{Fe}^{3+}$ & 0.058 & 0.024 & 0.095 & 0.070 & 0.110 \\
$\mathrm{Fe}^{2+}$ & 0.924 & 0.933 & 0.900 & 0.940 & 0.903 \\
$\mathrm{Mg}$ & 0.004 & 0.017 & 0.041 & 0.015 & 0.034 \\
$\mathrm{Zn}$ & 0.002 & 0.000 & 0.000 & 0.000 & 0.000 \\
$\mathrm{Mn}$ & 0.039 & 0.035 & 0.006 & 0.006 & 0.005 \\
$\mathrm{Zr}$ & 0.000 & 0.000 & 0.007 & 0.000 & 0.000 \\
$\mathrm{Nb}$ & 0.000 & 0.001 & 0.001 & 0.002 & 0.002 \\
\hline \% Hem & 3.0 & 1.3 & 5.1 & 3.6 & 5.7 \\
\% IIm & 97.0 & 98.7 & 94.9 & 96.4 & 94.3 \\
\hline \hline
\end{tabular}

1. OGA-48A, Amphibolite, Itivdlinguag

2. 163211, Diopside amphibolite, Bjфrneden

2. 163211, Diopside amphibolite, Bjфrneden

4. 163246, Cord-Anth-Garn gneiss (with rutile), s, shore

5. OGA-48L, Garn-Anth gneiss, Itivdlinguaq Ameragdla

* Total iron analyzed as $\mathrm{FeO} ; \mathrm{Fe}_{2} \mathrm{O}_{3}$ recalculated from

stoichiometry and end-member assignment. 
subequant to lath-shaped grains up to $500 \mu \mathrm{m}$ long. Sphene may occur with ilmenite, and is particularly abundant in diopside amphibolites, where two generations may be present: in those samples in which retrogressive metamorphism has caused the breakdown of diopside + hornblende to actinolite + epidote \pm chlorite, secondary sphene coronas have formed on ilmenite.

As shown by the analyses listed in Table 1 (Nos $1 \& 2$ ), ilmenite in amphibolites is characterized by moderate $\mathrm{MnO}(\sim 1.3-2.0 \mathrm{wt} \%)$ and low $\mathrm{MgO}(<0.5 \mathrm{wt} \%)$, and little to no $\mathrm{ZnO}, \mathrm{Al}_{2} \mathrm{O}_{3}, \mathrm{Cr}_{2} \mathrm{O}_{3}, \mathrm{ZrO}_{2}$ and $\mathrm{Nb}_{2} \mathrm{O}_{5}$. The hematite-content of the ilmenite, based on calculated $\mathrm{Fe}_{2} \mathrm{O}_{3}$, is low and ranges from 1-5 mole \%.

Pelitic and semi-pelitic schists. The most abundant Malene metasedimentary rock type is a semi-pelitic biotite + quartz + plagioclase \pm sillimanite schist containing garnet and cordierite. Locally, pelitic to subarkosic lithologies with abundant muscovite \pm alkali feldspar are also present. Garnet and cordierite occur in Fe- and $\mathrm{Mg}$-rich muscovite schists respectively, although cordierite is exceedingly rare in rocks that contain muscovite. Both the pelitic

Table 2. Microprobe analyses of rutile

\begin{tabular}{lrrrrrr}
\hline & 1 & 2 & 3 & 4 & 5 & \multicolumn{1}{c}{6} \\
\hline $\mathrm{SiO}_{2}$ & 0.04 & 0.04 & 0.00 & 0.05 & 0.00 & 0.03 \\
$\mathrm{TiO}_{2}$ & 98.19 & 93.17 & 90.72 & 98.17 & 99.34 & 98.01 \\
$\mathrm{Al}_{2} \mathrm{O}_{3}$ & 0.00 & 0.06 & 0.10 & 0.00 & 0.02 & 0.04 \\
$\mathrm{Cr}_{2} \mathrm{O}_{3}$ & 0.58 & 0.00 & 0.11 & 0.09 & 0.43 & 0.10 \\
$\mathrm{Fe}_{2} \mathrm{O}_{3} *$ & 0.00 & 2.18 & 3.06 & 0.38 & 0.05 & 0.36 \\
$\mathrm{MgO}$ & 0.00 & 0.00 & 0.01 & 0.00 & 0.00 & 0.00 \\
$\mathrm{ZnO}$ & 0.00 & 0.01 & 0.00 & 0.17 & 0.09 & 0.00 \\
$\mathrm{MnO}$ & 0.00 & 0.00 & 0.00 & 0.00 & 0.00 & 0.00 \\
$\mathrm{ZrO}{ }_{2}$ & 0.16 & 0.12 & 0.07 & 0.01 & 0.03 & 0.00 \\
$\mathrm{Nb}_{2} \mathrm{O}_{5}$ & 0.12 & 3.08 & 5.03 & 0.63 & 0.00 & 0.80 \\
$\mathrm{Total}^{2}$ & 99.09 & 98.66 & 99.10 & 99.50 & 99.96 & 99.34 \\
\hline
\end{tabular}

FORMULA PROPORTIONS BASED ON 1 CATION AND 2 OXYGENS

\begin{tabular}{lllllll}
$\mathrm{Si}$ & 0.001 & 0.001 & 0.000 & 0.001 & 0.000 & 0.000 \\
$\mathrm{Ti}$ & 0.982 & 0.949 & 0.930 & 0.988 & 0.992 & 0.989 \\
$\mathrm{Al}$ & 0.000 & 0.001 & 0.002 & 0.000 & 0.000 & 0.001 \\
$\mathrm{Cr}$ & 0.006 & 0.000 & 0.001 & 0.001 & 0.004 & 0.001 \\
$\mathrm{Fe}$ & 0.000 & 0.022 & 0.031 & 0.004 & 0.001 & 0.004 \\
$\mathrm{Mg}$ & 0.000 & 0.000 & 0.000 & 0.000 & 0.000 & 0.000 \\
$\mathrm{Zn}$ & 0.000 & 0.000 & 0.000 & 0.002 & 0.001 & 0.000 \\
$\mathrm{Mn}$ & 0.000 & 0.000 & 0.000 & 0.000 & 0.000 & 0.000 \\
$\mathrm{Zr}$ & 0.010 & 0.008 & 0.004 & 0.001 & 0.002 & 0.000 \\
$\mathrm{Mb}$ & 0.001 & 0.019 & 0.031 & 0.004 & 0.000 & 0.005 \\
\hline
\end{tabular}

GODTHÄBSFJORD-AMERALIK REGION 1. OGA-16, green mica quartzite; N. Shore Ameragdla

2. OGA-12B, Cord-Anth gneiss;

s. Coast Mitsimavigssuag

3. 163246, Cord-Anth-Garn gneiss (with Rutile); S. Shore Ameragdla

LANG $\emptyset$
4. OGA-28B, Orthopyroxene gneiss

5. OGA-35B, Pyribolite

6. $O G A-28 I-2$, Bitotite-rich Pyribolite

* Total iron analyzed as Feo; recalculated as $\mathrm{Fe}_{2} \mathrm{O}_{3}$ 
and semi-pelitic schists are typically rusty-weathering due to the presence of abundant sulfide minerals. Zircon, apatite, tourmaline and graphite are common accessory phases.

Ilmenite is by far the predominant Fe-Ti oxide in these rocks, although rutile occurs in several samples. Ilmenite ranges from stubby laths to blocky grains (up to $250 \mu \mathrm{m}$ across), and is a common inclusion in garnet porphyroblasts. Rutile forms subequant to elongated grains ranging from $25-100 \mu \mathrm{m}$ long.

The ilmenite analysis listed in Table 1 (No. 3) is typical of the compositions found, which are characterized by low $\mathrm{MnO}(0.2-0.4 \mathrm{wt} \%)$, low to moderate $\mathrm{MgO}(0.3-1.3 \mathrm{wt} \%)$, and small amounts of $\mathrm{Nb}_{2} \mathrm{O}_{5}(0.1-0.2 \mathrm{wt} \%)$. The contents of $\mathrm{ZnO}, \mathrm{Al}_{2} \mathrm{O}_{3}, \mathrm{Cr}_{2} \mathrm{O}_{3}$ and $\mathrm{ZrO}_{2}$ are at or near their detection limits $(<\sim 0.05 \mathrm{wt} \%)$. Calculated hematite-contents of the ilmenite are small, and range from 3-6 mole per cent. The few analyses carried out on rutile indicate that it is pure $\mathrm{TiO}_{2}$.

Green Mica Rocks. Perhaps the most striking, albeit least abundant, Malene metasedimentary rock type is a series of green mica schists that are referred to in the field as 'fuchsite quartzites'. The details of mica chemistry are reported by Dymek et al. (1983), who note that the green micas range in composition from nearly pure muscovite to types with up to $\sim 17$ wt $\% \mathrm{Cr}_{2} \mathrm{O}_{3}$ and $\sim 8$ wt $\% \mathrm{BaO}$.

Rutile is the only oxide present in green mica quartzites, and occurs as subequant, euhedral grains 50-100 $\mu \mathrm{m}$ across dispersed throughout each sample, and less commonly as irregularly shaped 5-10 $\mu \mathrm{m}$ wide inclusion in the mica. A typical analysis of rutile from this lithology is listed in Table 2 (No. 1), which shows that it is nearly pure $\mathrm{TiO}_{2}$, but contains some $\mathrm{Cr}_{2} \mathrm{O}_{3}, \mathrm{ZrO}_{2}$, and $\mathrm{Nb}_{2} \mathrm{O}_{5}$. Although there are exceptions, the $\mathrm{Cr}_{2} \mathrm{O}_{3}$-content of rutile in green mica rocks in higher than that found in other lithologies.

'Cordierite-Anthophyllite' rocks* (CAR). These constitute a widespread and characteristic metasedimentary lithology in the Malene supracrustals. The phase petrology of this rock type is quite complex, and involves various combinations of the minerals: Sill-Ky-Stl-CordGarn-Anth-Talc. Other minerals in CAR include abundant quartz, plagioclase and biotite, together with minor to trace quantities of apatite, corundum, monazite, sulfide, tourmaline and zircon.

Both ilmenite and rutile occur in CAR, the latter forming up to $\sim 3$ volume $\%$ in some samples. Ilmenite typically occurs as stubby plates up to $\sim 250 \mu \mathrm{m}$ long that are distributed uniformly throughout most samples, and as inclusions in garnet and anthophyllite. Rutile forms euhedral equant grains 50-100 $\mu \mathrm{m}$ across that also tend to be distributed evenly throughout a sample. However, in certain cases, rutile is found only as inclusions in garnet, whereas ilmenite occurs in the sample matrix. This petrographic feature suggests that the spatial distribution of Fe-Ti oxides in CAR is partly related to localized equilibration established during prograde continuous reactions.

In general, however, the occurrence of rutile and ilmenite is related to the nature of the coexisting silicate phase assemblage. As illustrated schematically in figure 2, rutile is restricted to $\mathrm{Mg}$-rich assemblages, and it is superceded by ilmenite in Fe-rich assemblages. The

* Anthophyllite is the name applied here to all orthorhombic amphiboles including types rich in Na and $\mathrm{Al}$, which could be called gedrite. There is no apparent compositional gap in the orthorhombic amphibole series in the Malene supracrustals, but rather a continuum of compositions (cf. Spear, 1980). 


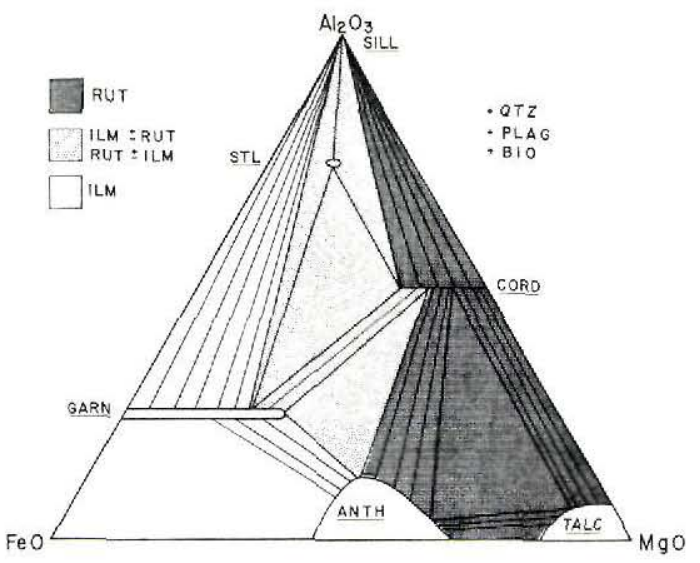

Fig. 2. Schematic representation of phase relationships in Malene 'cordierite-anthophyllite' rocks (CAR) from the Godthåbsfjord-Ameralik region for middle amphibolite metamorphic grade $\left(\sim 550^{\circ} \mathrm{C}\right)$. At higher grade, staurolite is absent, and tak and anthophyllite are replaced by orthopyroxene. At lower grade, staurolite coexists with anthophyllite, and kyanite may occur instead of sillimanite. Fields where rutile, ilmenite or both occur are indicated by the different patterns.

area of 'overlap' (i.e. ilmenite + rutile) varies from locality to locality, and is related not only to bulk composition, but also to metamorphic history, as indicated above. In addition, the presence of abundant sulfide minerals in some samples may affect a bulk composition shift to higher $\mathrm{Mg} /(\mathrm{Mg}+\mathrm{Fe})$ for the silicates and oxides, which could control the appearance of rutile vs. ilmenite.

The composition of ilmenite in CAR is not unlike that found in semi-pelitic schists, except that the concentration of $\mathrm{Nb}_{2} \mathrm{O}_{5}$ is commonly higher ( $\sim 0.2 \mathrm{wt} \%$; Table 1 , Nos 4 and 5$)$. The composition of rutile is unusual, and is characterized by large amounts of $\mathrm{Nb}$, reaching values as high as 6 wt $\% \mathrm{Nb}_{2} \mathrm{O}_{5}$ (Table 2 , Nos 2 and 3).

Substitution of niobium into rutile cannot occur directly for titanium due to differences in ionic charge. However, iron is also enriched in the rutile (cf. Table 2), which could provide a means of change compensation. $\mathrm{Nb}$ - and Fe-contents of several analyzed rutile grains are illustrated in figure 3 . The fact that the data points lie almost exactly on a 1:1 line suggests a coupled substitution of the following type:

$$
\mathrm{Nb}^{5+}+\mathrm{Fe}^{3+}=2 \mathrm{Ti}^{4+},
$$

and all iron has been recalculated to $\mathrm{Fe}_{2} \mathrm{O}_{3}$ accordingly.

Analytical totals for several rutile analyses are low (98-99 wt \%), even with iron recalculated to $\mathrm{Fe}_{2} \mathrm{O}_{3}$. Qualitative energy dispersive analyses indicate the presence of small amounts of tantalum $(<\sim 0.5$ wt $\%)$ which could account for this deficiency.

\section{Langø}

Pyribolites. The term 'pyribolite' was introduced by Berthelsen (1960) to describe mafic rocks metamorphosed at high-grade to the assemblage orthopyroxene + clinopyroxene + hornblende. On Langø, a variety of pyribolites are present, ranging from those containing $\mathrm{Cpx}+\mathrm{Opx}+\mathrm{Hbl}$ to types with abundant biotite or garnet. Plagioclase is abundant in all types, but quartz is typically absent, except in biotite-rich pyribolites where it may constitute up to 15 volume per cent of a given sample. Accessory apatite, sulfide and zircon occur in most samples, and green pleonaste spinel is found in garnet pyribolites. 
Fig. 3. Formula proportions $\mathrm{Nb}$ and $\mathrm{Fe}$ (based on 1 cation and 2 oxygens) in rutile from Malene 'cordierite-anthophyllite' rocks (CAR).

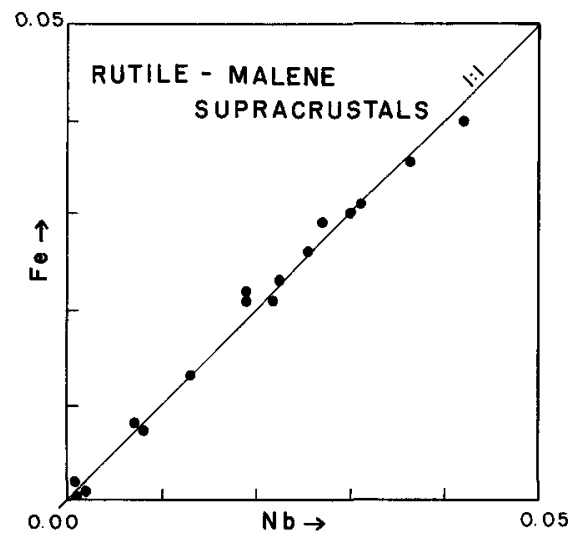

Various combinations of homogenous ilmenite, lamellar ilmenite-hematite intergrowths, and magnetite occur in pyribolites. These typically form polygonal grains up to $\sim 1 \mathrm{~mm}$ across, which occur interstitial to mafic minerals and plagioclase, and as inclusions in the mafic minerals. Rutile is a rare mineral in pyribolites, and where is does occur, the mafic silicates tend to be $\mathrm{Mg}$-rich. Ilmenite + rutile were noted in one sample.

The composition of ilmenite in pyribolites is highly variable. $\mathrm{MgO}$ - and $\mathrm{MnO}$-contents range from $\sim 0.5-1.2$ and $\sim 0.4-3.3$ wt $\%$ respectively. The concentrations of $\mathrm{Al}_{2} \mathrm{O}_{3}$, $\mathrm{Cr}_{2} \mathrm{O}_{3}, \mathrm{ZnO}, \mathrm{ZrO}_{2}$ and $\mathrm{Nb}_{2} \mathrm{O}_{5}$ are typically very low. Calculated hematite contents range from $\sim 2-11$ mole per cent, with the highest amounts found in ilmenite containing hematite lamellae.

Hematite lamellae in ilmenite contain 7-11 wt \% $\mathrm{TiO}_{2}$, but are otherwise relatively pure. No separate hematite grains were observed. Magnetite contains small amounts of $\mathrm{Al}_{2} \mathrm{O}_{3}$ and $\mathrm{Cr}_{2} \mathrm{O}_{3}(<0.50 \mathrm{wt} \%$ each), and is exceedingly Ti-poor. Recalculated magnetite compositions yield $<1$ mole per cent ulvospinel in all cases. Rutile is typically pure $\mathrm{TiO}_{2}$, but may contain up to $\sim 0.4 \mathrm{wt} \%$ each $\mathrm{Cr}_{2} \mathrm{O}_{3}$ and $\mathrm{Fe}_{2} \mathrm{O}_{3}$, and up to $\sim 0.8 \mathrm{wt} \% \mathrm{Nb}_{2} \mathrm{O}_{5}$. Representative analyses of Fe-Ti oxides in pyribolites are listed in Table 2 (Nos 4 and 5) and Table 3 (Nos 1-4).

Orthopyroxene gneiss. These are probably the higher-grade equivalents of CAR, and contain various combinations of the minerals Opx \pm Cord \pm Garn \pm Sill, together with abundant quartz, plagioclase and biotite. Accessory apatite, sulfide and zircon occur in most samples.

Ilmenite is the most abundant Fe-Ti oxide, and has compositions similar to those in CAR. Rutile also occurs in some samples, with the highest measured $\mathrm{Nb}_{2} \mathrm{O}_{5}$-content being $\sim 0.6$ wt \% (Table 2, No. 4).

Biotite Gneiss. A series of leucocratic gneisses containing the assemblage Bio + Qtz + Plag + Kfsp \pm Garn \pm Cord \pm Sill are probably the high-grade equivalents of the semipelitic to pelitic schists described above for the Godthåbsfjord-Ameralik region. Types with cordierite-garnet-sillimanite only contain ilmenite, whereas those without aluminous minerals (i.e. biotite gneiss sensu stricto) contain ilmenite or ilmenite + hematite. 
Table 3. Microprobe analyses of ilmenite, hematite and magnetite (Langø)

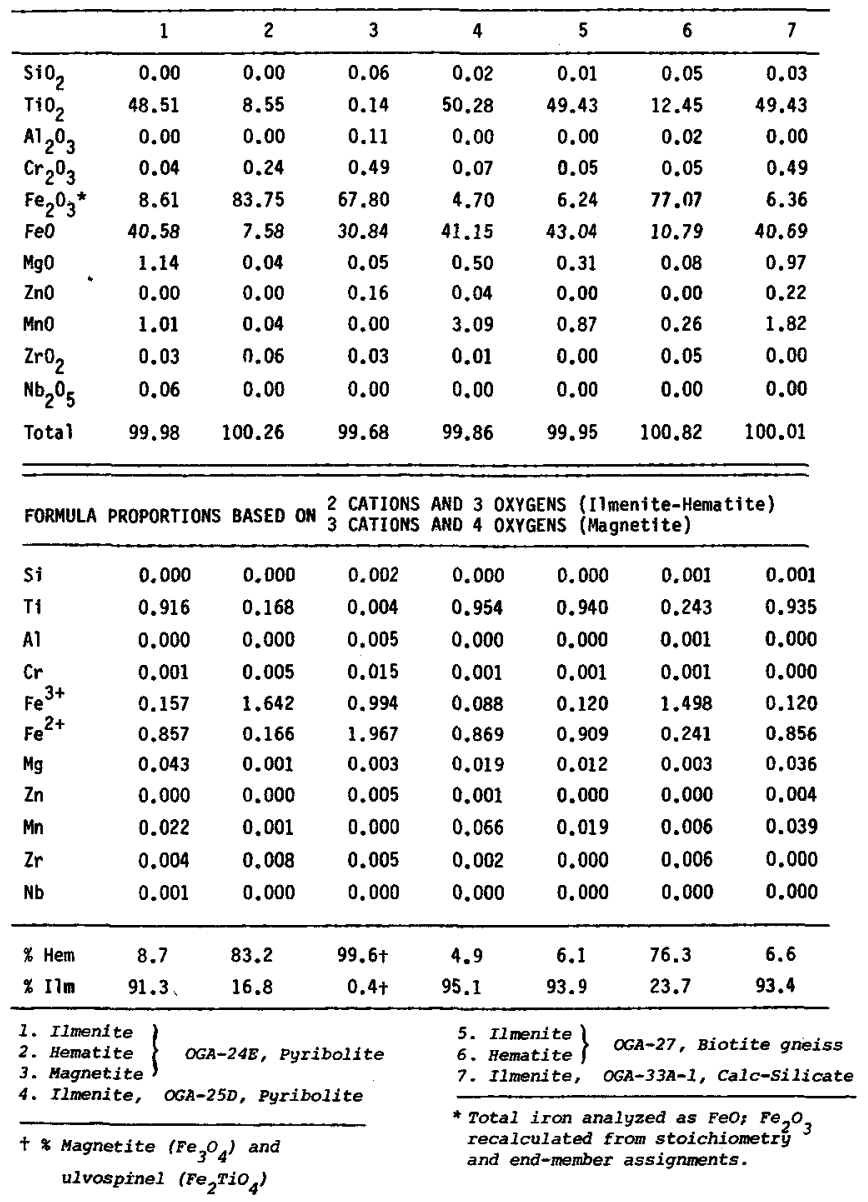

Ilmenite in the biotite gneisses contain $\sim 0.7-0.9 \mathrm{wt} \% \mathrm{MnO}$ and $\sim 0.3-0.7 \mathrm{wt} \% \mathrm{MgO}$, but only trace quantities of $\mathrm{Al}_{2} \mathrm{O}_{3}, \mathrm{Cr}_{2} \mathrm{O}_{3}, \mathrm{ZnO}, \mathrm{ZrO}_{2}$ and $\mathrm{Nb}_{2} \mathrm{O}_{5}$. Calculated hematite contents range from $6-9$ mole per cent.

Hematite contains from 11-13 wt \% $\mathrm{TiO}_{2}$ and small amounts of $\mathrm{MnO}(<0.4 \mathrm{wt} \%)$. Compositions of an ilmenite-hematite pair are listed in Table 3 (Nos 5 \& 6).

Calc-silicate gneiss. A rare lithology on Langø contains the assemblage quartz + plagioclase + scapolite + diopside \pm hornblende + sphene \pm grossular. Ilmenite is the only Fe-Ti oxide in these rocks, and forms elongated to stubby plates up to $\sim 1 \mathrm{~mm}$ long. The analysis listed in Table 3 (No. 7) is typical of the compositions found, and show that ilmenite contains high $\mathrm{MnO}(1.5-5.1 \mathrm{wt} \%)$, low $\mathrm{MgO}(0.5-1.0 \mathrm{wt} \%)$, $\mathrm{ZnO}(0.2-0.3 \mathrm{wt} \%)$ and $\mathrm{Cr}_{2} \mathrm{O}_{3}(0.4-0.6$ wt \%), but no detectable $\mathrm{ZrO}_{2}$ and $\mathrm{Nb}_{2} \mathrm{O}_{5}$. Calculated hematite contents range from 3-6 mole per cent. 
Fig. 4. Summary of Fe-Ti oxide assemblages in Malene supracrustal rocks from the Godthåbsfjord-Ameralik region.

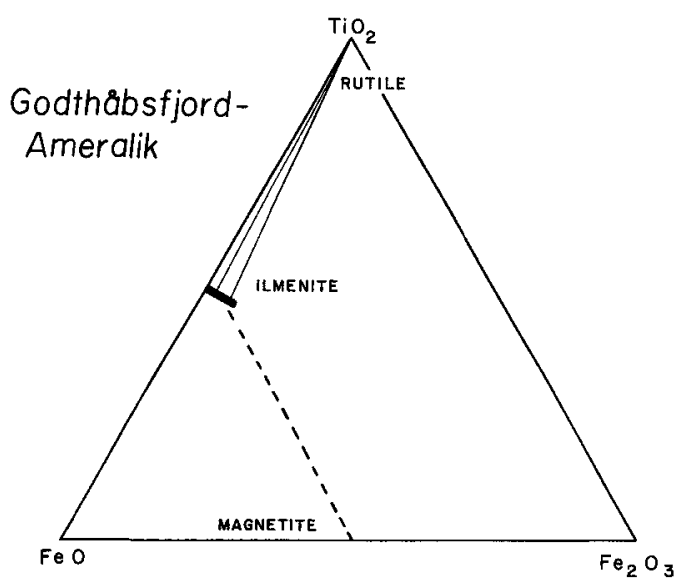

\section{Discussion}

\section{Fe-Ti oxide assemblages}

Prograde regional metamorphism of the Malene supracrustals at c. 2800 Ma ranged from middle amphibolite to granulite grade, and was followed by retrogressive metamorphism ranging from amphibolite to greenschist grade. Despite complexities associated with such polymetamorphism, the observed Fe-Ti oxide assemblages can be ascribed with some certainty to the main stage prograde metamorphic event. This conclusion is based on petrographic study of over three thousand samples.

$\mathrm{Fe}-\mathrm{Ti}$ oxide assemblages in Malene supracrustals from the Godthåbsfjord-Ameralik region are summarized in figure 4 , which shows the limited compositional range for ilmenite, and tie-lines connecting coexisting ilmenite-rutile pairs. In Malene amphibolites, only ilmenites is found (with or without sphene), whereas in metasedimentary lithologies, ilmenite, rutile or both are present. These observations suggest that variations in rock composition, rather than variable $f_{\mathrm{O}_{2}}$, provided the dominant control on oxide parageneses during regional metamorphism of the supracrustal rocks. Moreover, $\mathrm{f}_{\mathrm{O}_{2}}$ appears to have been uniformly 'low' ( $<\sim \mathrm{N}-\mathrm{NO}$ ), otherwise more oxidized assemblages containing hematite or rutile + magnetite would have formed. The low $\mathrm{Fe}_{2} \mathrm{O}_{3}$-content of the ilmenite (1-6 mole per cent) is also consistent with this conclusion.

Note that on figure 4, a dashed line has been drawn between ilmenite and magnetite. On Simiútat, a small island group west of Buksefjorden, magnetite has been identified in complex garnet corona structures in certain CAR. This occurrence has not been studied in detail, but the texture of the samples suggests that this magnetite formed during the development of the coronas, and is probably a result of retrograde metamorphism. However, as pointed out by Rumble (1976), a slight increase in Fe/Ti could convert an ilmenite \pm rutile assemblage to one containing ilmenite + magnetite, so that the conclusions reached here regarding low $\mathrm{f}_{\mathrm{O}_{2}}$ need not be modified.

Oxide assemblages observed on Langø are summarized in figure 5. Ilmenite occurs in all lithologies, whereas magnetite is largely restricted to pyribolites. Hematite, commonly as lamellae in ilmenite, is found in pyribolites and in a few biotite gneisses. These relationships 


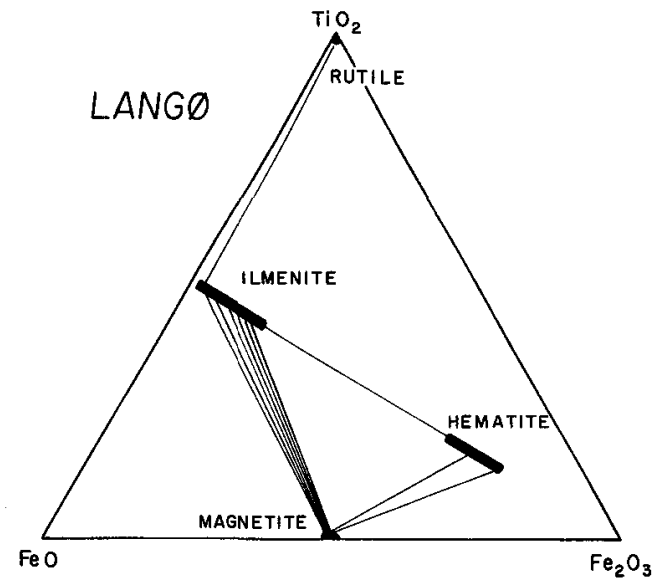

Fig. 5. Summary of Fe-Ti oxide assemblages in supracrustal gneisses on Langø.

suggest that bulk composition in part controlled oxide parageneses. The relatively large compositional range of ilmenite, and the occurrence of ilmenite-magnetite, hematitemagnetite, and ilmenite-hematite pairs suggest equilibration over a modest range of $f_{\mathrm{O}_{2}}$. However, the regular orientations of tie lines indicates equilibration at similar $\mathbf{T}-\mathrm{f}_{\mathrm{O}_{2}}$ conditions for all oxides.

It is important to emphasize that the granulite-grade gneisses on Langø contain hematite and magnetite, and ilmenite with a higher $\mathrm{Fe}_{2} \mathrm{O}_{3}$-content than found in samples from amphibolite-grade supracrustals from the Godthåbsfjord-Ameralik region. This suggests slightly higher $\mathrm{f}_{\mathrm{O}_{2}}$ during granulite-grade $v s$. amphibolite-grade metamorphism. A general discussion of the various mechanisms that could control or buffer $\mathrm{f}_{\mathrm{O}_{2}}$ during metamorphism is clearly beyond the scope of this report. However, it is possible that high temperature dissociation of $\mathrm{H}_{2} \mathrm{O}$ in the fluid phase to $\mathrm{H}_{2}$ and $\mathrm{O}_{2}$, with subsequent preferential diffusive loss of hydrogen, could result in a more oxidizing environment under granulite grade conditions. Nevertheless, the principal point here is that the results of this study do not support the contention that granulite-grade metamorphism occurs under more reducing conditions than amphibolite-grade metamorphism. Additional study is needed to investigate this problem, particularly in regard to any uncertainties related to polymetamorphism and the role of fluids in high-grade metamorphism.

\section{Niobian rutile}

The occurrence of $\mathrm{Nb}$-rich rutile in CAR is interesting and merits further discussion. One possible explanation is that the high $\mathrm{Nb}$-content is simply a consequence of the fact that during metamorphism rutile concentrates that element in the same way that staurolite concentrates $\mathrm{Zn}$ or garnet $\mathrm{Mn}$. Although such an effect is probably important in some samples, petrographic study indicates no correlation between modal abundance of rutile and $\mathrm{Nb}$-content. In addition, CAR contain an inordinately large amount of zircon, up to $\sim 1$ modal per cent. These observations point towards an absolute enrichment of $\mathrm{Nb}$ and $\mathrm{Zr}$ in CAR, but the exact magnitude of this enrichment must await detailed geochemical study. CAR have been interpreted as 'restites' from partial melting processes (e.g. Grant, 1968; 
Lal \& Moorhouse, 1969; Gribble, 1970). Although an enrichment in refractory elements such as $\mathrm{Nb}$ and $\mathrm{Zr}$ would be consistent with this hypothesis, the inferred conditions of metamorphism and absence of field evidence for melting in CAR throughout the Godthåbsfjord-Ameralik region would preclude the partial melting model (cf. Dymek, 1978).

Vallance (1967) has suggested that the protolith of CAR represents the residue from hydrothermal alteration of mafic volcanic rock. In West Greenland, CAR are commonly associated with amphibolites, and it is possible that some type of alteration process prior to metamorphism caused enrichment in $\mathrm{Nb}$ and $\mathrm{Zr}$, which was followed by reworking in a sedimentary environment. This hypothesis is not inconsistent with the field occurrence, and may be the most plausible explanation.

An alternative to models involving alteration is that the protolith of CAR was actually a sediment of unusual composition, and the rutile and zircon constitute part of a reworked detrital component, with the composition of the rutile inherited from its source material. Natural examples of $\mathrm{Nb}$-rich rutile are rare, but are known to occur in alkalic igneous rocks and kimberlites (cf. Deans, 1966; Clark \& Mitchell, 1975; Dawson \& Smith, 1977). Although it is premature to suggest that rutile and zircon in CAR constitute evidence for alkalic igneous activity in the Archaean craton of West Greenland, it will be interesting to determine whether high $\mathrm{Nb}$ and $\mathrm{Zr}$ are unique to the CAR in the Godthåbsfjord-Ameralik region, or are characteristic of CAR in general.

Acknowledgments. This work has been supported by the National Science Foundation (Grants DES75-03417 and EAR 78-23412). Most of the microprobe analyses referred to in this report were carried out at the California Institute of Technology, and the analytical tecniques used are described by Dymek (1977a). Comments on the manuscript by staff members of the Geological Survey of Greenland have been most useful.

\section{References}

Berthelsen, A. 1960: Structural studies in the pre-Cambrian of western Greenland. II. Geology of Tovqussaq nunâ. Bull. Grønlands geol. Unders. 25 (also Meddr Grønland 123) 223 pp.

Bridgwater, D., Keto, L., McGregor, V. R. \& Myers, J. S. 1976: Archaean gneiss complex of Greenland. In Escher, A. \& Watt, W. S. (edit.) Geology of Greenland, 20-25. Copenhagen: Geol. Surv. Greenland.

Clarke, D. B. \& Mitchell, R. H. 1975: Mineralogy and petrology of the kimberlite from Somerset Island, NWT, Canada. Phys. Chem. Earth 9, 123-136.

Dawson, J. B. \& Smith, J. V. 1977: The MARID (mica-amphibole-rutile-ilmenite-diopside) suite of xenoliths in kimberlite. Geochim. cosmochim. Acta 41, 309-323.

Dean, T. 1966: Economic mineralogy of African carbonatites. In O. F. Tuttle \& J. Grittins (edit.) Carbonatites, 385-413. New York: Interscience.

Dymek, R. F. 1977a: Mineralogic and petrographic studies of Archaean metamorphic rocks from West Greenland, lunar samples, and the meteorite Kapoeta. Unpubl. Ph.D. dissertation, California Institute of Technology, Pasadena.

Dymek, R. F. 1977b: Phase relations in Archaean Malene supracrustal rocks from Itivdlinguaq, Godthåb District, West Greenland. Geol. Soc. Amer. Abstr. 9, 960-961.

Dymek, R. F. 1978: Metamorphism of Archaean Malene supracrustals, Godthåb District, West Greenland. (Abstract). In Smith, I. E. M. \& Williams, J. G. (edit.) Proceedings 1978 Archean Geochemistry Field Conference, 339-342. Univ. Toronto Press. 
Dymek, R. F. \& Albee, A. L. 1976: Polymetamorphic Archaean gneisses from Langø, West Greenland. Geol. Soc. Amer. Abstr. 8, 848-849.

Dymek, R. F., Boak, J. L. \& Kerr, M. T. 1983: Green micas in the Archaean Isua and Malene supracrustal rocks, southern West Greenland, and the occurrence of a barian-chromian muscovite. Rapp. Grønlands geol. Unders. 112, 71-82.

Grant, J. A. 1968: Partial melting of common rocks as a possible source of cordierite-anthophyllite bearing assemblages. Amer. J. Sci. 266, 908-931.

Gribble, C. D. 1970: The role of partial fusion in the genesis of certain cordierite-bearing rocks. Scott. J. Geol. 6, 75-82.

Lal, R. K. \& Moorhouse, U. U. 1969: Cordierite-gedrite rocks and associated gneisses of Fishtail Lake, Harcourt Township, Ontario. Canad. J. Earth Sci. 6, 145-165.

McGregor, V. R. 1973: The early Precambrian gneisses of the Godthab District, West Greenland. Phil. Trans. R. Soc. Lond. A273, 343-358.

Rumble, D. 1976: Oxide minerals in metamorphic rocks. Chapter 3 in: Miner. Soc. Amer. Short Course Notes, Oxide Minerals 3.

Spear, F. S. 1980: The gedrite-anthophyllite solvus and the compositon limits of ortho-amphibole from the Post Pond Volcanics, Vermont. Amer. Miner. 65, 1103-1118.

Vallance, T. G. 1967: Mafic rocks alteration and isochemical development of some cordierite-anthophyllite rocks. J. Petrology 8, 84-96. 